\title{
HOUSEHOLD DEBT IN POLAND IN THE YEARS 2005-2017 - LEGAL ANALYSIS OF THE CASE OF SWISS FRANC LOANS. A CONTRIBUTION TO DEBATE
}

\author{
Agnieszka Żywicka*
}

\begin{abstract}
The subject of the article is the problem of the legal construction of loans denominated and indexed with a foreign exchange rate (CHF), which were incurred by Polish consumers in 2005-2017 and their repayment. The main problem analyzed in the article is the issue of repayment of franc loans noticed and analyzed both in scientific circles (by lawyers, economists, sociologists) and by politicians, which testifies to the significance and size of the phenomenon. This article will present individual views and proposals of the author in relation to Polish conditions, primarily from the legal point of view, the author firstly presents the legal construction of the loan, then presents the positions of banks and courts and proposes the cancellation of the contract and the conversion of some of its provisions.
\end{abstract}

Key words: credit in foreign currency, the consumer

\section{INTRODUCTION. RATIONALE FOR THE CHOICE OF THE TOPIC ARTICLE}

From the beginning of the 21st century, in particular in the years 2005 -2008, banks operating in Poland granted consumers mortgage loans tied to the exchange rate of a foreign currency, primarily to Swiss francs $(\mathrm{CHF})$.

Doctor hab. of legal sciences, Instytut Prawa, Ekonomii i Administracji, Wydział Prawa, Administracji i Zarządzania, Uniwersytet Jana Kochanowskiego w Kielcach, agnieszka.zywicka@onet.eu. 
Due to the prevailing social relations, most of these loans were taken out by married customers, which had a significant influence on the financial conditions of their households.

The major advantage of such loans were relatively lower interest rates than in the case of a zloty loan at that time. This was reflected in lower payments, which meant that borrowers were not only able take a larger loan than in the case of a zloty loan, but also to have any credit capacity in situations where they would not qualify for a domestic currency loan. After the Swiss franc rate soared following the global financial crisis and the decision of the Swiss National Bank to lift the minimum exchange rate as of 15 January 2015, the value of liabilities of Polish borrowers expressed in that currency increased dramatically. In response to the currency crisis, the Act amending the Banking Law Act and several other laws ${ }^{1}$ of 29 July 2011 was adopted. What is commonly known as the "Anti-spread Law" introduced the possibility to pay the installments of an indexed or redenominated loan directly in a foreign currency. It has not, however, solved any significant issues in respect of Swiss franc loans ${ }^{2}$.

The analysis of the problem must take into account the events over the last dozen years, both in terms of the economy and the legal structure of loans, as the rate of the Swiss franc changed significantly. The debt of borrowers increased, which often left them insolvent. The recent years have seen mounting claims of the so-called "franc debtors" who tried to have their loan agreements cancelled in court. This had a negative impact on the image of banks, traditionally perceived as institutions of public trust. In the meantime, financial problems of Polish households affect the economic and financial condition of the country. According to BIK (Polish Credit Information Bureau), there were 500000 active franc mortgage loans in Poland as of October 2017, whereas the total number of liable borrowers amounted to $868320^{3}$. Swiss franc loan agreements comprise both Swiss franc-indexed loans and redenominated loans $s^{4}$.

Journal of Laws No. 165, item 984.

2 Ryszard Szewczyk, „Ekonomiczne, prawne i etyczne aspekty kredytów frankowych” [Economic, legal, and ethical aspects of Swiss franc loans], Bank i Kredyt 48(5), 2017: p. 452 .

As cited in the Press Release of the Polish Credit Information Bureau of 11 December 2017 . 
Increasing loan payments reduce the consumer capacity of Poles, thus impeding their possibility of acquiring consumer goods. This, in turn, negatively affects the general economic condition of the country and decelerates its economic growth. Partial destabilization of the banking system, i.e. reduced level of customer confidence in the banking industry, also impinges upon the financial security of the country and contributes to the general weakness of the Polish zloty against other currencies.

This paper will examine the claim that the franc loan agreement is invalid, but it should be permissible to rectify this legal transaction by switching it into a zloty loan on the grounds of the social relations, legitimate interest of the parties, and valid customs.

\section{OBJECTIVE, METHODOLOGY AND SCOPE OF RESEARCH}

The difficulty regarding the repayment of franc loans has become the object of attention and analysis both of scientists (in respect of law, economy, and sociology) and politicians, which is telling of how pressing and grave the situation is. This article will present authors' personal views and proposals, primarily from a legal perspective, in the Polish context. The specificity of loan agreements, however, also calls for a reference to economic matters, which are further discussed in the article Legal, economic and ethical aspects of franc loans by R. Szewczyk ${ }^{5}$, as well as in Swiss franc loan and Polish zloty loan - perspective of a cash flow change by A. Barembruch ${ }^{6}$.

The aim of this paper is the legal assessment of the validity of borrower claims based on a synthetic analysis of agreements regarding for-

4 Błażej Gadek, „Dopuszczalność stosowania klauzul indeksacyjnych umów kredytowych" [Permissibility of indexation clauses in loan agreements], Monitor Prawniczy, 12(2018): p. 662.

5 Ryszard Szewczyk, „Ekonomiczne, prawne i etyczne aspekty kredytów frankowych" [Economic, legal, and ethical aspects of Swiss franc loans], Bank i Kredyt 48(5), 2017: pp. 455-459.

Adam Barembruch, „Kredyt frankowy a kredyt złotowy - perspektywa zmian cash-flow" [Swiss franc loan and Polish zloty loan - perspective of a cash flow change] Finanse, Rynki Finansowe, Ubezpieczenia [Finance, financial markets, Insurance], 4(82/2), pp. 805-820. DOI: 10.18276/frfu.2016.4.82/2-69. 
eign currency-indexed or redenominated loans. For this purpose, the authors applied firstly the dogmatic legal and legal comparative method to examine legal provisions, and then the legal-comparative method to analyse the jurisprudence of common courts in cases under consideration. Finally, with the aim of developing a comprehensive and original measure, the authors carried out an evaluation of the legal situation of borrowers and banks in Poland and subsequently propose possible solutions to the problem.

\section{LEGAL AND ECONOMIC DEFINITION OF A LOAN VS. FOREIGN CURRENCY LOAN - STRUCTURE OF AGREEMENT}

In order to determine whether borrowers' claims are valid or not, it is necessary to first provide the definition of a loan. This is one of the fundamental concepts in the banking law7. Pursuant to Article 69 (1) of the Banking $\mathrm{Law}^{8}$, the bank lends a specific amount of money to the borrower for a period of time specified in the agreement for a particular objective as one of the essentialia negotii of loan agreements.

The legal doctrine describes the concept of a loan in the economic approach', whereby it is a relation between the bank and the borrower, on the basis of which the bank provides the borrower with a specific amount of money, whereas the borrower undertakes to reimburse that amount along with with remuneration in the form of an origination fee ${ }^{10}$. Swiss franc loans, however, may not be categorised as foreign currency loans as they do not meet the criteria set out in the definition of such loans. A foreign currency loan is expressed, given, and repaid

7 Beata Paxford, “Commentary on Article 69" In: "Prawo bankowe” [Banking Law], ed. Hanna Gronkiewicz-Waltz, Warsaw 2013: p. 239.

8 Act of 29 August 1997 - Banking Law, Vol. 1. Journal of Laws 2017, Item 1876 as amended.

9 Janusz Molis In: "Prawo bankowe” [Banking Law]. Comment. Vol. 1, ed. Fryderyk Zoll, Krakow 2013, p. 673; also: Zbigniew Ofiarski In: „Prawo bankowe” [Banking Law], ed. Zbigniew Ofiarski, Warsaw 2013, Commentary on Article 69, p. 483.

10 Remigiusz Kaszubski, Agata Tupaj- Cholewa, „Prawo bankowe” [Banking Law]. Warsaw 2010, p. 50. 
in a foreign currency ${ }^{11}$. Moreover, the borrowers of franc loans did not need funds in a foreign currency for purchasing property located in Poland as they did. The only purpose of banks which offered a loan tied to a foreign exchange rate was to increase the demand for new "products" in their portfolio. There was therefore no transfer of the foreign currency from the bank to the borrower, while the amount of the loan was paid to the borrower in Polish currency (PLN).

There were two types of loan available in the legal system, i.e. indexed and redenominated loans. The indexed loan, granted in Polish currency, was recalculated at the time of payment to the foreign currency according to the purchase exchange rate. The loan value calculated was the basis for calculation of the repayment installments and the amount of the borrower's debt. The installments were then recalculated again into PLN at the selling rate at the date of repayment, specifying the obligation of the borrower. In the case of the redenominated loan, the amount was determined in foreign currency, but it was paid in Polish currency, according to the purchase exchange rate, whereas loan installments, also expressed in foreign currency, were to be repaid in PLN at the selling rate at the date of repayment ${ }^{12}$.

From the economic point of view, the structure of loan agreements is generally well-founded as to disparities in the relation between the creditor and the borrower. For economists, a loan is a financial instrument and a bank product. The borrower voluntarily and knowingly consents to the risks associated with the currency rate to which the rate of PLN exchange is tied. This applies both to a low exchange rate and an increase in the exchange rate. Customers are therefore not deceived by banks in any way, and neither do banks abuse their position ${ }^{13}$.

11 Jacek Czabański, „Walutowe klauzule waloryzacyjne w umowach kredytów hipotecznych. Analiza problemu" [Currency adjustment clauses in mortgage loan agreements. Analysis of the problem], Palestra 6/2016: p. 63.

12 Report of the Financial Ombudsman, "Analiza prawna wybranych postanowień umownych stosowanych przez banki w umowach kredytów indeksowanych do waluty obcej lub denominowanych w walucie obcej zawieranych z konsumentami" [Legal analysis of selected contractual provisions applied by banks in consumer agreements for loans indexed to foreign currency or redenominated in a foreign currency], Warsaw 2016, p. 9.

13 More on this topic for example in: Ryszard Szewczyk, „Ekonomiczne, prawne...”; Adam Barembruch, „Kredyt frankowy a kredyt złotowy...”. 
From a legal perspective, however, the situation is much more complex. Not only is the content of the loan agreement analysed, but also all the circumstances in which the agreement was concluded, as well as the possibility of the parties to the agreement to perform their obligations. It is a highly controversial situation when the capital to be repaid is higher than at the time the measures were received after several years of repayment. This is unfortunately very common in the case of Swiss franc loan agreements. In practice, this means that the borrower is unable to fulfill the liability, which is one of the grounds on which the agreement may be invalidated pursuant to Article 387 (2) of the Civil Code (CC) ${ }^{14}$.

\section{INVALIDITY OF LOAN AGREEMENTS TIED TO THE EXCHANGE RATE OF SWISS FRANC AND RECTIFICATION OF AN INVALID LEGAL TRANSACTION - PROPOSED POSITION.}

A civil law concept, loan agreement belongs to the category of legal transactions (agreements) of a bilateral, pecuniary, and reciprocal nature, effective upon submission of declarations of will by the parties. Pursuant to the Article $56 \mathrm{CC}$, the effects of a legal transactions include not only the effects explicitly expressed therein, but also those which result from the law, social relations, and established practices. The abovementioned provision is the prescriptive basis for distinguishing the three substantive elements of the content of a legal transaction. These include the essentialia (essential elements without which the legal transaction could not be performed and which determine the legal classification of legal transactions), incidentalia (additional elements introduced by the parties to achieve intended effects), and naturalia (items not covered in the content of the legal transaction) which result from default rules ${ }^{15}$.

The assessment of the franc loan agreement is based on the abovementioned Article 69 (1) of the Banking Law. "In a loan agreement, the bank provides the borrower with a specific amount of money, whereas

14 Act of 23 April 1964 - Civil Code, Vol. 1. Journal of Laws 2018, item 1025. (CC).

15 Marek Safjan In: “Civil Code. Commentary. Vol. 1.” ed. Krzysztof Pietrzykowski, Warsaw 2015, p. 272. 
the borrower undertakes to use it on the conditions laid down in the agreement, to reimburse that amount along with with interest according to the payment schedule, and to pay the origination fee for the loan granted". The provision in question is a ius cogens and may not be modified by the parties, as it stipulates the constitutive requirements with which a loan agreement must comply (essentialia negotii). Pursuant to this provision, the essentialia negotii of a bank loan agreement should primarily comprise the obligation of the bank to provide the borrower with a specific amount of money with a particular objective for a period of time specified in the agreement, as well as the obligation of the borrower to repay the amount of the loan they were granted. The provisions of Article 69 (1) of the Banking Law correspond with Article 69 (2)(2) of the Banking Law, which clearly sets out the requirement to determine the amount and the currency of the loan. Therefore, any contractual provisions which are contradictory to this statutory requirement must be deemed as void. This also applies to the provisions of agreements which attempt to circumvent the law (Article 58 (1) and (3) CC in reference to Article 69(1) of the Banking Law). Such is the nature of provisions stipulating the loan indexation to a foreign currency rate (indexation clauses), in particular with respect to the Swiss franc. Such a provision must be considered as one of the provisions which define the main obligations of the parties.

For the correct classification of relevant contractual provisions, it is helpful to draw a distinction between principal and ancillary obligations ${ }^{16}$, as it has been distinguished in the Polish Civil Law for decades. In view of the above, provisions which specify the principal obligations of the parties regard the elements of the legal transaction which belong to the essentialia, whereas the other provisions, subject to assessment as to their so-called abusive nature, comprise the remaining elements of the content of legal transactions. The legal doctrine rightly indicates that the provisions on the so-called indexation clauses have a decisive influence on the shape of the agreement and should be therefore regarded as provisions determining

16 Wojciech Popiołek In: „Civil Code. Commentary. Vol. 1.” ed. Krzysztof Pietrzykowski, Warsaw 2015, p. 1247; Zbigniew Radwański, Adam Olejniczak, „Zobowiązania - część ogólna” [Liabilities - general information], Warsaw 2014, p. 49. 
the principal obligations of the parties ${ }^{17}$. Consequently, the so-called indexation clauses would disappear from the agreement, deeming the legal transaction along with its effect as invalid.

An additional argument which may support the need for invalidating loan agreements concluded prior to 2009 is the content of the principle of currency orientation, which was applicable when the vast majority of franc loans were concluded. Pursuant to Article $358 \mathrm{CC}$ in its wording at the time, "financial liabilities in the territory of the Republic of Poland may be expressed only in the Polish currency, subject to exceptions provided for by law." 18 This provision was a ius cogens, thus all contractual provisions regarding the loan amount indexation and the recalculation of loan installments were aimed at circumventing it. By means of indexation clauses, banks attempted to achieve a result prohibited by mandatory provisions. The prohibition of expressing obligations of parties in foreign currencies was circumvented as the obligations of parties were redenominated in Polish currency. The agreement was executed in the Polish currency indeed, but the amount of obligations would be dependent on the exchange rate of another currency. The objective of the bank was therefore to achieve the same result as if the agreement expressed the obligations in a foreign currency.

The party to the agreement which was aware of their inability to perform the obligation may be required to remedy the loss the other party to the agreement incurred because they were not aware at the time of concluding the agreement that the performance of the obligation was impossible. Pursuant to the abovementioned Article 387 (2) CC, the party to an agreement for the performance of an impossible obligation is legally protected in situations where one of the parties to such an agreement knew at the time of concluding the agreement that the performance of the obligation is impossible. This provision is the legal basis for customer

17 Krzysztof Zagrobelny In:, „Civil Code. Commentary.” eds. Edward Gniewek, Piotr Machnikowski, Warsaw 2014, p. 696, and Adam Olejniczak, In: "Civil Code. Commentary”, "Zobowiązania - część ogólna” [Liabilities - general information], Vol. 3, Part 1, p. 220.

18 Principle of currency orientation was in force in Poland until 23 January 2009, it was abolished as a result of the revision of the civil code (Journal of Laws 2008 No. 228, item 1506). 
claims for damages against banks as a result of improperly structured loan agreements.

\section{RECTIFICATION OF A LEGAL ACTION IN EFFECTIVE SUBSTITUTE LEGAL}

The rectification of a legal transaction by converting it into a valid transaction is a legal concept both in the doctrine and in the case law. Pursuant to the jurisdiction of the Supreme Court, the ratio legis of the rectification procedure is that the main objective of the parties is to achieve an economic purpose, which in fact conditions the will of the parties. It is characteristic of the rectification procedure that it attempts to maintain the declared intentions of the parties at least partially, so that the given transaction may achieve the result sought by the parties at least to a certain extent ${ }^{19}$.

Should an indexed loan agreement become null and void, it is necessary to consider whether it is possible to rectify the agreement by converting it into a zloty loan, i.e. according to the rules that would allow for the attainment of the objective which the parties intended to achieve, i.e. a loan being granted, at least to some extent ${ }^{20}$.

The legal doctrine rightly assumes that the rectification may be applied in the following conditions: firstly, if the legal transaction to replace the invalid transaction has the same socio-economic objective; secondly, if the parties did not know about the invalidity of the legal transaction; thirdly, if there is a possibility to establish a hypothetical will of the parties whereby they would have performed a substitute legal transaction if they had known of the invalidity of the legal transaction in question ${ }^{21}$.

19 Cf. decision of the Supreme Court of 8 August 1986, OSNCP 1987 No. 8, item 108, judgement of the Supreme Court of 26 November 2002, V CKN 1445/00, OSNC 2004, No. 3, item 47, and judgement of the Supreme Court of 9 May 2001, II CKN $425 / 00$, judgement of the Supreme Court of 5 February 2010, III CSK 105/09, LEX No. 951735.

20 Cf. decision of the Supreme Court of 8 June 1986 III PECS 51/86, LEX No. 3265.

21 Janina Preussner- Zamorska, „Nieważność czynności prawnej w prawie cywilnym” [Invalidity of legal transactions in civil law], Warsaw 1983, p. 155. 
"Should an invalid legal transaction comply with the legal requirements of another legal transaction, the invalid transaction is converted into another effective legal substitute (rectification) if the substitute legal transaction allows for attaining the same or a similar objective to the objective of the invalid legal transaction" 22 . According to the civil law, a legal transaction contradicts the law also when the the transaction does not subsist of any content or other elements prescribed pursuant to legal standards ${ }^{23}$.

To conclude, it should be stressed that the original legal transaction made by the parties was the conclusion of the loan agreement in zloty. The fact that a loan was granted in Polish currency implies that the borrowers had the capacity to take out a zloty loan and all their efforts were aimed at obtaining funds in Polish zlotys and not in Swiss francs (which $n b$ the borrower never received from the lender). The objective of the contracting parties was therefore to establish a loan relationship, whereas the conclusion of the agreement was not contingent upon the invalid provisions i.e. indexation clauses.

\section{Selected decisions of courts and administrative bodies on Swiss franc loan agreements}

From the point of view of the parties, as usual for contentious cases, the most important factor in the absence of an agreement regarding consensual change of the terms and conditions of an agreement is the jurisprudence of courts. There are numerous court proceedings currently in progress, where a redenominated or indexed loan constitutes the factual basis. The jurisprudence in this regard is in favour of the borrowers. The vast majority of courts acknowledge the claims of the borrowers, deeming the loan agreements invalid increasingly more often, e.g. on the basis of Article 58 (1) CC in reference to Article 69 of the Banking Law and Article $353^{1} \mathrm{CC}$ or Article 58 (1) CC in reference to Article 69(2)(5) of the Banking Law, thus committing banks to reimburse the unduly received funds. According to the predominant view, the currency of the loan is determined by the currency in which the bank paid the funds pursuant to the agreement; the

22 Wojciech Piekarski In: „Civil Code. Commentary”, Warsaw 1972, p. 170.

23 Judgement of the Court of Appeal in Katowice of 19 January 2018, I ACa 632/17, LEX No. 2453699. 
loan constitutes the amount of money transferred to the borrower. It is typical of the agreement for a loan in zloty redenominated to a foreign currency rate that the bank undertakes to provide the borrower with an amount expressed in PLN equivalent to the amount expressed in foreign currency indicated in the agreement, whereas the subject of the contractual obligation is an amount expressed in PLN and this is the only amount the borrower may receive ${ }^{24}$.

In one of the newer decision of the Katowice Court of Appeal, i.e. in its judgement of 19 January 2018, the court stressed that the provisions of an agreement which allow the bank to arbitrarily choose the purchase and sale rate of a foreign currency for the purpose of loan settlement resulted obvious shortcomings of the agreement in terms of transparency of the regulation which enables the consumer entering an agreement with the bank to gauge the degree of financial risk related to the loan repayment. Pursuant to the Article 3851 (1) CC, provisions regulating the rights and obligations of the consumer in a manner which is contrary to the accepted principles of morality and poses a serious threat to the interest of the consumer, and which were not agreed upon individually, are not binding for the consumer. However, if there were no conditions regulating the changes in interest rates included in the loan agreement, the agreement was contrary to the law within the meaning of Article $58 \mathrm{CC}$. A legal transaction contradicts the law also when the the transaction does not subsist of any content or other elements prescribed pursuant to legal standards. The Article 69 of the Banking Law at the time clearly indicated that the provisions regulating the conditions of a loan interest change must be set out in the agreement. The court in Katowice, similarly to the Court of First Instance, deemed the instructions on the consequences of the conclusion of the agreement for a foreign currency-indexed loan and the resulting risk that the defendants received as consumers to be insufficient, in particular in relation to the benefits achievable by borrowers, and therefore contrary to the accepted principles of morality (Article 58 (3) CC) $)^{25}$.

24 Judgement of the Court of Appeal in Bialystok of 6 December 2017, I ACa 558/17, see the judgement of the District Court for Warsaw-Wola of 25 January 2016, No. I C 1750/16; judgement of the District Court for Łódź-Śródmieście of 27 September 2016, No. XVIII C 4360/15; judgement of the District Court of Warsaw-Praga of 02 December 2016, No. III C 75/16).

25 Judgement of the Court of Appeal in Katowice of 19 January 2018, I ACa 632/17. 
The Court of Competition and Consumer Protection in Warsaw also analysed the contractual provisions relating to the indexation of loans and repeatedly proved them to be abusive by means of the abstract control procedure ${ }^{26}$. Unfair Contract Terms Register contains many provisions of loan agreements considered unfair (abusive), e.g. according to the judgement of the Court of Competition and Consumer Protection of 27 December 2010, XVII AmC 1531/09 under No. 5743, the judgement of the Court of Competition and Consumer Protection of 3 August 2012, XVII AmC 5344/11 No 5622, and the judgement of the Court of Competition and Consumer Protection of 14 December 2010, XVII AmC 426/09 under No. 3178 and 3179. Indexation clause in loan agreements, which grants banks the unlimited right to unilaterally regulate the amount of loan payments and the interest rate indexed to the Swiss franc exchange rate, was deemed an abusive clause in the case law (cf. the judgement of the District Court in Torun of 13 July 2016, No I C 916/16).

\section{SUMMARY}

Considerations presented in this article do not address the issue in its entirety, as it requires a much broader monographic elaboration. The remarks put forth in the article will hopefully prompt further discussion and reflection.

The conclusions regarding the legal structure of a loan agreement tied to the foreign currency rate provide a general outline of this phenomenon, but manage to show the prescriptive nature of the issue. It is therefore possible to prove the thesis advanced at the outset of the article regarding the invalidity of Swiss franc loan agreements and the permissibility of rectifying an invalid legal transaction. The solution proposed is also a compromise for the both parties to the agreement, as it is difficult to accept the situation where the capital to be repaid is the same or even higher after several years of repayment than at the time the meas-

26 Judgements of the Court of Competition and Consumer Protection (SOKiK) of 14 December 2010, No. XVII AmC 426/09; of 26 January 2011, No. XVII AmC 1531/09; of 25 June 2014, No. XVII AmC 8868/12, Legalis. 
ures were received on the pretext of the principle of freedom of contract being a paramount rule to determine the content of agreements and the way they are concluded in the legal system, given that these loans pertain mainly to the consumer, and are taken out to meet the residential needs of their families. It is crucial to give careful consideration to limitation clauses which restrict the freedom of contract as to loans (e.g. exploitation, social relations, principles of morality). In this respect, the common sense approach of courts is of utmost importance, as they have a real influence on the economic market practices and resolve situations in which the position of a participant of legal system is at risk. It is extremely important that the courts weigh the interests of the parties. It must be noted, however, that the claims in question are a relatively new challenge for Polish courts, with first claims files only in 2014, but they surely will be more and more common, taking into account the number of loans. It is also possible, although unlikely, that the banks will agree to resolve disputes amicably and rectify franc-indexed or redenominated loan agreements by converting them into zloty loans. This, however, requires time, while the problem with loan repayment concerns hundreds of thousands of households in Poland.

\section{REFERENCES}

Barembruch Adam, „Kredyt frankowy a kredyt złotowy - perspektywa zmian cash-flow" [Swiss franc loan and Polish zloty loan - perspective of a cash flow change] Finanse, Rynki Finansowe, Ubezpieczenia [Finance, financial markets, Insurance], 4(82/2): 805-820. DOI: 10.18276/frfu.2016.4.82/2-69.

Czabański Jacek, 2016, „Walutowe klauzule waloryzacyjne w umowach kredytów hipotecznych. Analiza problemu" [Currency adjustment clauses in mortgage loan agreements. Analysis of the problem], Palestra 6.

Gadek Błażej, 2018, „Dopuszczalność stosowania klauzul indeksacyjnych umów kredytowych" [Permissibility of indexation clauses in loan agreements], Monitor Prawniczy, No 12.

Kaszubski Remigiusz, Tupaj- Cholewa Agata, 2010, „Prawo bankowe” [Banking Law]. Warsaw, Wolters Kluwer.

Molis Janusz, 2013 In: "Prawo bankowe" [Banking Law]. Comment. Vol. 1, ed. Zoll Fryderyk, Krakow. 
Ofiarski Zbigniew, 2013, In: „Prawo bankowe” [Banking Law], ed. Ofiarski Zbigniew, Warsaw, Wolters Kluwer.

Paxford Beata, 2013, Commentary on Article 69 In: "Prawo bankowe" [Banking Law], ed. Hanna Gronkiewicz-Waltz, Warsaw, C.H. Beck.

Piekarski Wojciech, 1972, In: „Civil Code. Commentary.”,Warsaw. Popiołek Wojciech, 2015, In: „Civil Code. Commentary. Vol. 1”. ed. Pietrzykowski Krzysztof, Warsaw, C.H. Beck.

Preussner- Zamorska Janina, 1983, „Nieważność czynności prawnej w prawie cywilnym" [Invalidity of legal transactions in civil law], Warsaw, PWN.

Report of the Financial Ombudsman, 2016, "Analiza prawna wybranych postanowień umownych stosowanych przez banki w umowach kredytów indeksowanych do waluty obcej lub denominowanych w walucie obcej zawieranych z konsumentami" [Legal analysis of selected contractual provisions applied by banks in consumer agreements for loans indexed to foreign currency or redenominated in a foreign currency], Warsaw.

Radwański Zbigniew, Olejniczak Adam, 2014, „Zobowiązania - część ogólna” [Liabilities - general information], Warsaw. C.H. Beck.

Safjan Marek, 2015, In: "Civil Code. Commentary. Vol. 1." ed. Pietrzykowski Krzysztof, Warsaw, C.H. Beck.

Szewczyk Ryszard, 2017, „Ekonomiczne, prawne i etyczne aspekty kredytów frankowych" [Economic, legal, and ethical aspects of Swiss franc loans], Bank i Kredyt 48(5): 452.

Zagrobelny Krzysztof, 2014, In: „Civil Code. Commentary”. eds. Gniewek Edward, Machnikowski Piotr, Warsaw, C.H. Beck. 